\section{US-812 Citrus Rootstock}

\section{Kim D. Bowman}

U.S. Horticultural Research Laboratory, U.S. Department of Agriculture, Agricultural Research Service, 2001 South Rock Road, Ft. Pierce, FL 34945

\section{Robert E. Rouse}

Institute of Food and Agricultural Sciences, University of Florida, 2686 S.R. 29 North, Immokalee, FL 34142

Additional index words. grapefruit, orange, mandarin, cultivar, breeding, genetics

'US-812' is a new citrus rootstock released May 2001 by the Agricultural Research Service (ARS) of the U.S. Dept. of Agriculture (USDA). Compared to other citrus rootstocks used in Florida, US-812 is highly productive of good quality fruit on a moderate-sized tree and exhibits tolerance or resistance to citrus tristeza virus (CTV) and citrus blight. US-812 propagates uniformly from seed (by nucellar polyembryony) and is graft compatible with all scion cultivars examined, including sweet orange [Citrus sinensis (L.) Obsbeck], grapefruit (C. paradisi Macf.), mandarin ( $C$. reticulata Blanco), tangelo (C. reticulata $\times C$. paradisi), and other citrus hybrids.

\section{Origin}

US-812 is the result of a cross between Sunki mandarin (C. reticulata) and Benecke trifoliate orange (Poncirus trifoliata [L.] Raf.) completed at the USDAIndio Research Station, California. During the early stages of testing, this hybrid selection was moved as seed to the U.S. Horticultural Research Laboratory in Orlando, Florida for the rootstock evaluation process. While under test in Florida, the new rootstock selection was identified as Sunki $\times$ Benecke, HRS-812, or US-812. Seed for all greenhouse and field evaluations described below was obtained from the field source tree WFF 1-132-46.

Fruit for descriptive characteristics of US812, Swingle citrumelo, and Carrizo citrange was collected from the USDA Whitmore Foundation Farm at fruit maturity during the 2002 and 2003 crop seasons. Leaf and spine descriptive characteristics were collected from young greenhouse seedlings of each clone during 2001-2002. Field trials conducted as part of the performance documentation for US-812 were established into the field sites between 1989 and 2000, and data collected using common methods. Details on trial locations, soils, management, and preliminary results were described in previous publications, as indicated. Evaluation of rootstock resistance to pests and disease were based on comparative field performance, greenhouse testing, or

Received for publication 22 Nov. 2004. Accepted for publication 20 Oct. 2005. Mention of a trademark, warranty, proprietary product, or vendor does not imply an approval to the exclusion of other products or vendors that also may be suitable. This research was supported in part by the Florida Citrus Production Research Advisory Council, Project No. 025-02I.
As commonly used, US-812 forms the rootstock of the tree, with a good quality fruit cultivar grafted onto US-812 about 10 to 20 $\mathrm{cm}$ above the ground. Fruit of the US-812 rootstock clone are needed to produce seed for economical multiplication of the rootstock. For this purpose, mature US- 812 shoots are budded onto another rootstock variety and grown to produce a fruiting tree. Characteristics of the US-812 fruit are similar to those of many hybrids from similar parentage, but distinctive from many other rootstocks in commercial use (Fig. 1). Quantitative fruit and seed traits of US-812 are clearly distinguished from Carrizo citrange $(C$. sinensis $[$ L.] Osbeck $\times$ P. trifoliata $)$ and Swingle citrumelo (C. paradisi Macf. $\times P$. trifoliata) (Table 1).

US-812 seed produces seedlings that are predominantly derived from maternal tissue by apomixis and thus are clonally identical to US-812. In experimental populations of US-812 seedlings, frequency of off-type or zygotic seedlings has been less than five percent. Like many other first-generation hybrids of Poncirus trifoliata with Citrus spp., US-812 seedlings are vigorous, healthy, and possess trifoliolate leaves with winged petioles (Fig. 2). US-812 seedlings can be readily separated from seedlings of the two most common $P$. trifoliata hybrid rootstocks in commercial use, Swingle and Carrizo, based on leaf and spine characteristics (Table 2). Grafted trees of citrus cultivars on US-812 rootstock typically have some rootstock overgrowth of the scion (or

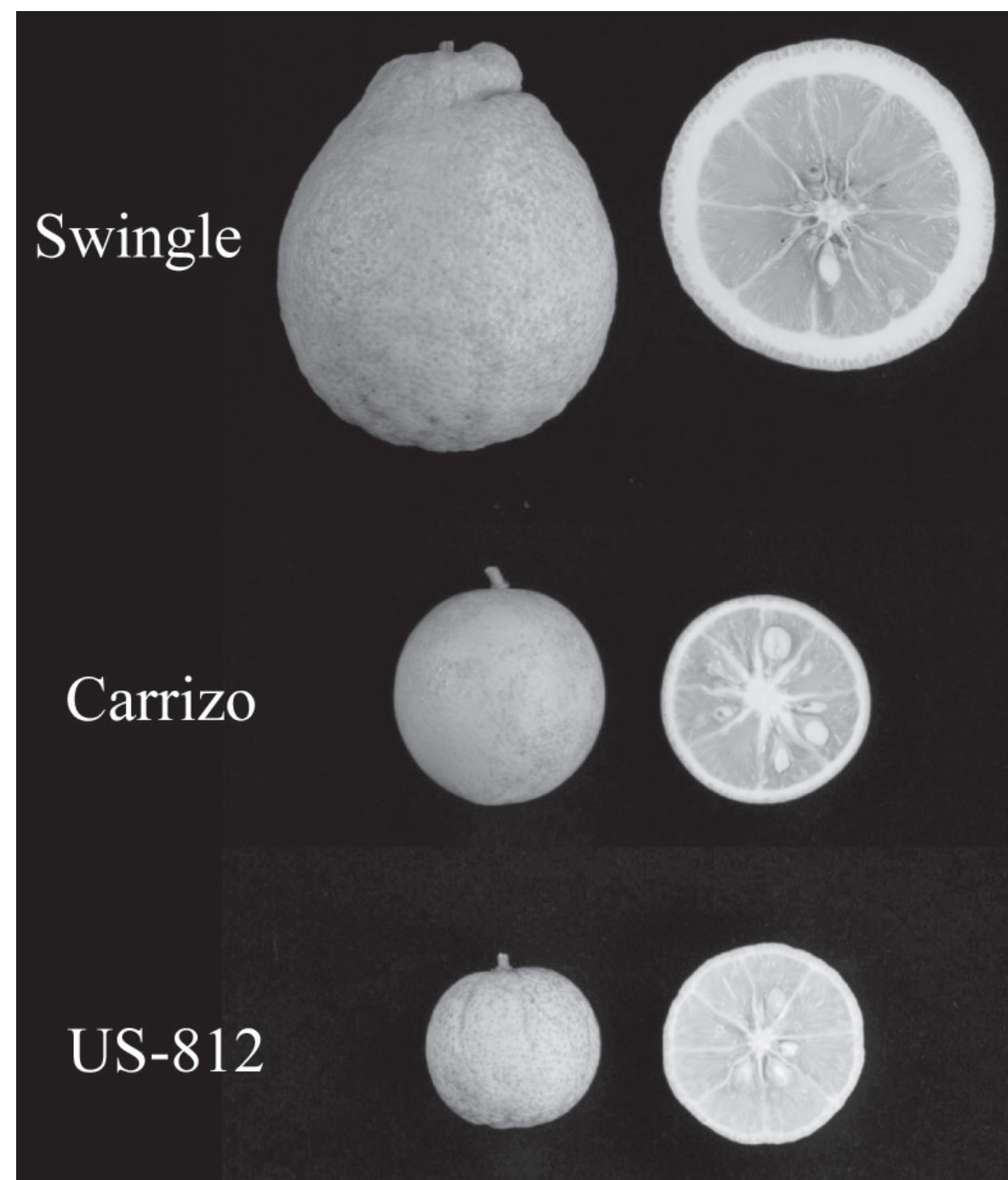

Fig. 1. Whole and cut fruit of Swingle, Carrizo, and US-812 at maturity. 
Table 1. Fruit and seed characteristics of US-812, compared with two common citrus rootstocks.

\begin{tabular}{lccr}
\hline Trait & $\begin{array}{c}\text { Swingle } \\
\text { citrumelo }\end{array}$ & $\begin{array}{c}\text { Carrizo } \\
\text { citrange }\end{array}$ & US-812 \\
\hline Fruit weight $(\mathrm{g})$ & $289 \mathrm{~A}^{\mathrm{z}}$ & $136 \mathrm{~B}$ & $63 \mathrm{C}$ \\
Fruit length $(\mathrm{mm})$ & $85 \mathrm{~A}$ & $65 \mathrm{~B}$ & $50 \mathrm{C}$ \\
Fruit diameter $(\mathrm{mm})$ & $86 \mathrm{~A}$ & $65 \mathrm{~B}$ & $52 \mathrm{C}$ \\
Seeds per fruit & $26 \mathrm{~A}$ & $23 \mathrm{~A}$ & $15 \mathrm{~B}$ \\
Seed weight $(\mathrm{mg})$ & $23.2 \mathrm{~B}$ & $35.3 \mathrm{~A}$ & $18.3 \mathrm{C}$ \\
Seed length $(\mathrm{mm})$ & $12.5 \mathrm{~B}$ & $14.3 \mathrm{~A}$ & $10.6 \mathrm{C}$ \\
Seed diameter $(\mathrm{mm})$ & $6.9 \mathrm{~B}$ & $8.8 \mathrm{~A}$ & $6.5 \mathrm{C}$ \\
Seeds per liter & $3226 \mathrm{~A}$ & $1942 \mathrm{~B}$ & $3670 \mathrm{~A}$ \\
\hline
\end{tabular}

${ }^{\mathrm{z}}$ Mean separations for significant ANOVA within rows were by Duncan's multiple range test at $P<0.01$.

benching) similar to that of many other trifoliate hybrid rootstocks, and are not particularly distinctive in physical appearance (Fig. 3).

\section{Performance}

Field performance of US- 812 was evaluated through 10 or more years of age in six Florida plantings. In each of these plantings, performance of US-812 was good or outstanding in comparison to other commercial rootstocks included in the planting. Several other field plantings were evaluated for shorter periods of time. Overall, performance in most field plantings was good, as described below.

Yield. Four long-term trials were conducted in well-drained Florida "ridge" sites. Trees were planted in a randomized manner with other comparison rootstocks and yield was carefully measured through at least six consecutive harvest seasons. In one rootstock trial in Polk County with 'Valencia' sweet orange on 21 rootstocks, US-812 was the first or second most productive rootstock through the fourth harvest season (Wutscher and Bowman, 1999), depending on the unit of yield measurement compared. When the yield comparison was continued through the sixth harvest season in this trial (Table 3), US-812 yield appeared

Fig. 2. Greenhouse-grown seedling shoots of Swingle, Carrizo, and US-812.

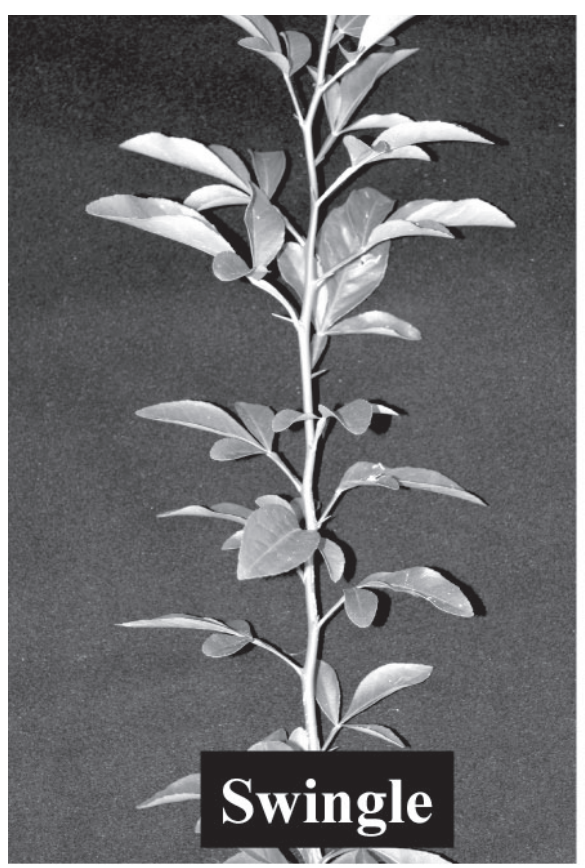

clearly superior to all of the other commercial rootstocks in the trial, including Swingle, Carrizo, Gou Tou, Sun Chu Sha, and Vangasay lemon. In three Lake County trials, with 'Sunburst' (Table 4), 'Fallglo' (Table 5), and 'Ambersweet' (Table 6) citrus hybrid scions, yield of trees on US-812 through the first six harvest seasons was good or outstanding in comparison to other commercial rootstocks. Preliminary performance of US-812 in these trials was reported previously (Bowman, 1998; Bowman and Roman, 1999).

Performance of US-812 in Florida flatwoods sites was evaluated in one long-term randomized trial and one nonrandomized planting in St. Lucie County, one long-term nonrandomized planting in Hendry County, and several other shorter-term randomized trials at other sites. Performance in some of these plantings and in Puerto Rico was described previously (Bowman and Roman, 1999; Bowman and Wutscher, 2001). At all the plantings where data were recorded, yield performance of US-812 has been good.

Yield of several sweet orange scions on US-812 was compared to that on three other rootstocks in a Collier County trial at the University of Florida, Southwest Florida Research \& Education Center near Immokalee. For trees with 'Hamlin' scions, yield on US-812 was significantly better than that of trees on X-639 (a commercially available hybrid of $C$. reticulata $\times$ Poncirus trifoliata) through the four seasons from age five to eight (Table 7). During the same time period, 'Valencia' scion yield on US-812 was equal to that of X-639 and US-1001 (another USDA hybrid that has not been released) and significantly better than yield on Kinkoji (C. obovoideae), another new commercially available rootstock (Table 8). Yield of midseason sweet oranges on US-812 in the trial was good but not statistically different from that of trees on the other rootstocks in the test (data not shown).

In two young 'Flame' grapefruit trials in St. Lucie and Indian River Counties, yield of trees on US-812 was good in comparison to trees on other rootstocks (Table 9). During the first harvest season for the St. Lucie County trial, yield of trees on US-812 was similar to that on the highest yielding rootstock, rough lemon (C. jambiri Lush.), and significantly better than that on Swingle, Sun Chu Sha, US-802 (an unreleased USDA hybrid), and Flying Dragon rootstocks. Although yield of grapefruit trees on US-812 in the Indian River County trial was good in comparison to Carrizo, Swingle, and Cleopatra rootstocks, its overall performance at that site would probably be judged poor. Further discussion of the likely explanation for this poor performance is given in the disease resistance section below.

Tree size. Comparative height of trees on US-812 at 6-10 years was evaluated in four trials, all on Florida "ridge" sites (Table 10). Trunk Cross Sectional Area is also a measure of relative trees size and was compared for different rootstocks in the Indian River County grapefruit trial. Some variability was observed by trial and should be expected in response to different scions, soils, growing conditions, and disease pressure. In general, under good growing conditions trees on US-812 were smaller those on rough lemon and Carrizo, similar in size to those on Swingle and Sun Chu Sha, and larger than trees on Flying Dragon.

Fruit quality. Measurements of fruit quality

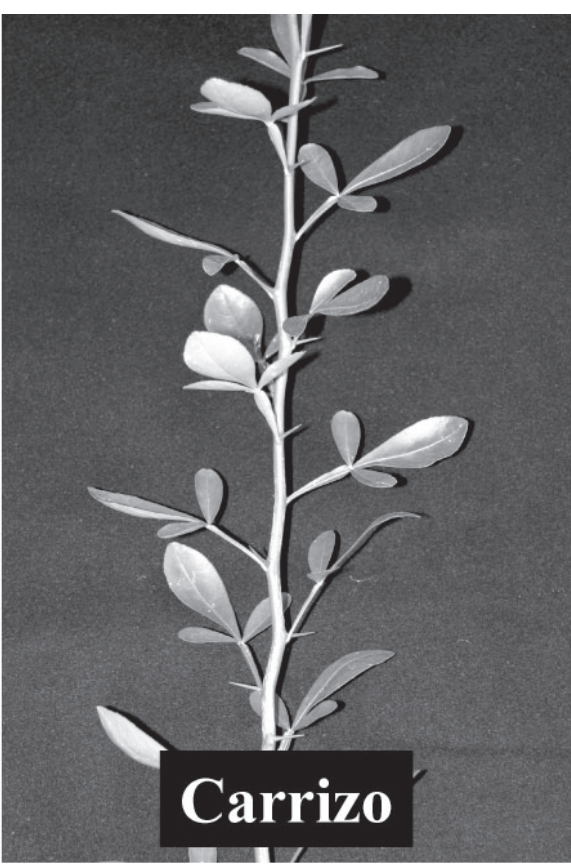


Table 2. Seedling leaf and spine characteristics of US-812, compared with two common citrus rootstocks.

\begin{tabular}{lccr}
\hline Trait & $\begin{array}{c}\text { Swingle } \\
\text { citrumelo }\end{array}$ & $\begin{array}{c}\text { Carrizo } \\
\text { citrange }\end{array}$ & US-812 \\
\hline Center leaflet length $(\mathrm{mm})$ & $55.5 \mathrm{~A}^{\mathrm{z}}$ & $41.1 \mathrm{C}$ & $44.7 \mathrm{~B}$ \\
Center leaflet width $(\mathrm{mm})$ & $24.6 \mathrm{~A}$ & $19.1 \mathrm{C}$ & $21.0 \mathrm{~B}$ \\
Side leaflet length $(\mathrm{mm})$ & $32.8 \mathrm{~A}$ & $22.4 \mathrm{C}$ & $25.4 \mathrm{~B}$ \\
Side leaflet width $(\mathrm{mm})$ & $15.1 \mathrm{~A}$ & $10.3 \mathrm{C}$ & $11.4 \mathrm{~B}$ \\
Petiole length $(\mathrm{mm})$ & $20.0 \mathrm{AB}$ & $21.4 \mathrm{~A}$ & $18.5 \mathrm{~B}$ \\
Petiole width $(\mathrm{mm})$ & $3.9 \mathrm{~A}$ & $4.1 \mathrm{~A}$ & $2.9 \mathrm{~B}$ \\
Spine length $(\mathrm{mm})$ & $5.3 \mathrm{~B}$ & $7.9 \mathrm{~A}$ & $8.8 \mathrm{~A}$ \\
\hline
\end{tabular}

${ }^{2}$ Mean separations for significant ANOVA within rows were by Duncan's multiple range test at $P<0.01$.

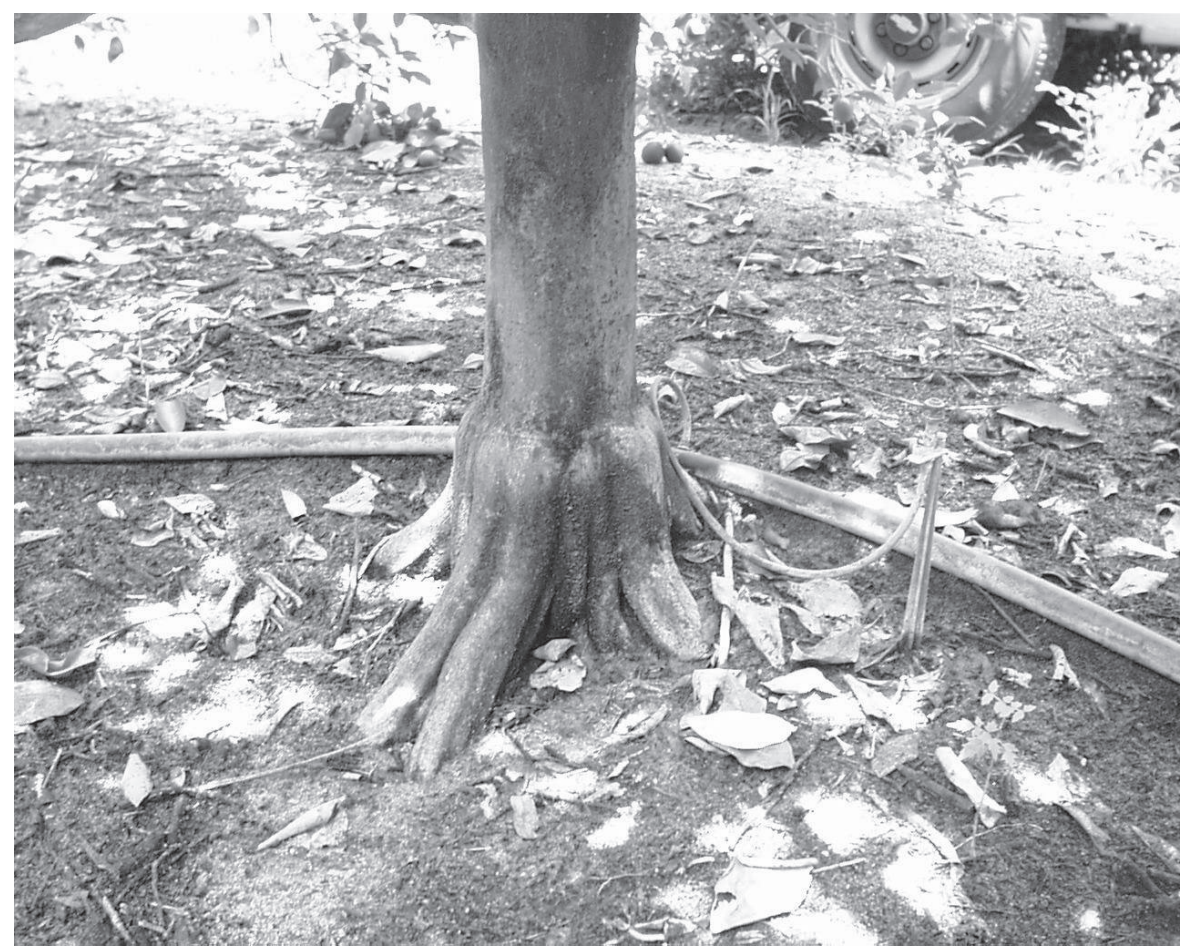

Fig. 3. Base of mature 'Valencia' sweet orange tree on US-812 rootstock showing typical graft union on a field tree.

Table 3. Yield of Valencia sweet orange on US-812 and other rootstocks in Polk County, 1996-2001.

\begin{tabular}{lccccccc}
\hline & \multicolumn{5}{c}{ Fruit yield (kg/tree) } & Yearly \\
\cline { 2 - 7 } Rootstock & Year 4 & Year 5 & Year 6 & Year 7 & Year 8 & Year 9 & avg $^{z}$ \\
\hline US-812 & $41 \mathrm{~b}^{\mathrm{y}}$ & $61 \mathrm{a}$ & $90 \mathrm{~b}$ & $114 \mathrm{a}$ & $122 \mathrm{a}$ & $103 \mathrm{a}$ & $107 \mathrm{a}$ \\
Vangasay lemon & $54 \mathrm{a}$ & $51 \mathrm{a}$ & $120 \mathrm{a}$ & $92 \mathrm{~b}$ & $119 \mathrm{ab}$ & $68 \mathrm{c}$ & $100 \mathrm{a}$ \\
Swingle & $38 \mathrm{bc}$ & $39 \mathrm{~b}$ & $75 \mathrm{c}$ & $87 \mathrm{~b}$ & $90 \mathrm{c}$ & $91 \mathrm{ab}$ & $86 \mathrm{ab}$ \\
Carrizo & $25 \mathrm{c}$ & $29 \mathrm{bc}$ & $75 \mathrm{c}$ & $86 \mathrm{~b}$ & $109 \mathrm{ab}$ & $82 \mathrm{bc}$ & $88 \mathrm{ab}$ \\
Sun Chu Sha & $29 \mathrm{bc}$ & $29 \mathrm{c}$ & $66 \mathrm{c}$ & $60 \mathrm{c}$ & $105 \mathrm{bc}$ & $63 \mathrm{c}$ & $74 \mathrm{~b}$ \\
Sour orange \#2 & $7 \mathrm{~d}$ & $3 \mathrm{~d}$ & $21 \mathrm{~d}$ & $23 \mathrm{~d}$ & $21 \mathrm{~d}$ & $29 \mathrm{~d}$ & $23 \mathrm{c}$ \\
\hline
\end{tabular}

${ }^{2}$ Yearly average based on years 5 to 8 .

${ }^{y}$ Mean separations for significant ANOVA within rows were by Duncan's multiple range test at $P<0.05$.

Table 4. Yield of Sunburst tangerine on US-812 and other rootstocks in Lake County, years 1996-2001.

\begin{tabular}{|c|c|c|c|c|c|c|c|}
\hline \multirow[b]{2}{*}{ Rootstock } & \multicolumn{6}{|c|}{ Fruit yield (kg/tree) } & \multirow{2}{*}{$\begin{array}{l}\text { Yearly } \\
\text { avg }^{2}\end{array}$} \\
\hline & Year 4 & Year 5 & Year 6 & Year 7 & Year 8 & Year 9 & \\
\hline$\overline{\mathrm{US}}-812$ & 19 & $66 \mathrm{a}^{y}$ & $22 \mathrm{ab}$ & $108 \mathrm{a}$ & 66 & $158 \mathrm{a}$ & 84 \\
\hline Carrizo & 36 & $54 \mathrm{a}$ & $39 \mathrm{a}$ & $116 \mathrm{a}$ & 53 & $147 \mathrm{a}$ & 82 \\
\hline Cleopatra & 34 & $43 \mathrm{ab}$ & $44 \mathrm{a}$ & $84 a b$ & 48 & $101 \mathrm{~b}$ & 64 \\
\hline Swingle & 19 & $45 \mathrm{ab}$ & $13 \mathrm{~b}$ & $81 \mathrm{ab}$ & 44 & $101 \mathrm{~b}$ & 57 \\
\hline Sun Chu Sha & 31 & $22 \mathrm{bc}$ & $25 \mathrm{ab}$ & $65 \mathrm{bc}$ & 33 & $90 \mathrm{bc}$ & 47 \\
\hline US-937 & 19 & $10 \mathrm{c}$ & $8 \mathrm{~b}$ & $32 \mathrm{c}$ & 24 & $55 \mathrm{c}$ & 26 \\
\hline
\end{tabular}

${ }^{2}$ Yearly average based on years 5 to 9 .

'Mean separations for significant ANOVA within rows were by Duncan's multiple range test at $P<0.05$.

were taken in all the trials described. Although there was variability between trials and between years, in general, the influence of US-812 rootstock on the scion fruit quality was good, especially as relates to fruit for juice production. When sweet orange fruit is grown for use in orange juice concentrate (a major part of Florida orange production), quantity of soluble solids per $40.9 \mathrm{~kg}$ box of fruit is probably the most important component of fruit quality. Fruit quality data from trials with 'Valencia' (Table 11) and 'Hamlin' oranges (Table 12), indicated that production of soluble solids by US- 812 is similar to the best of the commercially used rootstocks and often significantly better than that on X-639 and Vangasay lemon. Influence of US-812 on fresh fruit internal quality (brix, acid, juice, color) was also generally good, such as with 'Sunburst' tangerine (Table 13). However, individual fruit size on US-812 was often smaller than on many other rootstocks. In cases where large fruit size is important for successful marketing of the crop, US-812 may not be suitable. Preliminary studies have indicated that US-812 imparts a moderate to favorable effect on post-harvest storage life of grapefruit(McCollum etal., 2002) and Valencia orange (Ritenour et al., in press).

Disease and pest resistance. Health, growth, and survival of trees on US-812 were generally good in trials conducted in Florida. Evidence on tolerance of important disease threats can be derived from performance in some of these trials. In the Polk County Valencia trial, trees on sour orange were unproductive (Table 3 ) and severely stunted (Table 10), in addition to having a high proportion of tree loss. This extremely poor performance of sour orange rootstock provides clear evidence for a severe challenge in that trial from citrus tristeza virus (CTV) (Bowman and Garnsey, 2001). In contrast, trees on US-812 in the trial were uniformly healthy, moderately vigorous, and highly productive. This evidence, combined with the presence of flanking markers for the citrus tristeza virus (CTV resistance gene from Poncirus trifoliata in US-812 (data not presented), provide evidence that US-812 has resistance or tolerance to CTV infection and decline.

There was also good survival of trees on US-812 in long-term plantings in Hendry and St. Lucie Counties, while neighboring trees on other rootstocks failed. Many of these trees losses on other rootstocks were probably due to blight (Wutscher et al., 1977) or blight-like soil disease problems. The St. Lucie County Valencia trial was under conditions of high soil $\mathrm{pH}(8.1$ to 8.3$)$ and the good performance of US-812 there may be indicative of some tolerance of high alkalinity.

Good performance of trees on US-812 at many sites also suggests some resistance to Phytophthora nicotianae diseases, which are common in most production areas. However, greenhouse inoculation tests of US-812 alongside other rootstocks have indicated that US812 is relatively susceptible to Phytophthora palmivora, especially in soils with poor drainage (Bowman et al., 2002). In addition, greenhouse testing of US-812 for resistance to the Diaprepes root weevil (Diaprepes abbreviatus) has indicated that US-812 is as susceptible as most other common rootstocks in commercial use (Bowman et al., 2001). These greenhouse test results are reinforced by field observations at a young trial with grapefruit in Indian River County infested by Diaprepes weevil and $P$. palmivora on heavy Winder soil (Bowman et 
Table 5. Fallglo scion in Lake County, years 1996-2001.

\begin{tabular}{|c|c|c|c|c|c|c|c|}
\hline \multirow[b]{2}{*}{ Rootstock } & \multicolumn{6}{|c|}{ Fruit yield (kg/tree) } & \multirow{2}{*}{$\begin{array}{c}\text { Yearly } \\
\text { avg }^{2}\end{array}$} \\
\hline & Year 4 & Year 5 & Year 6 & Year 7 & Year 8 & Year 9 & \\
\hline$\overline{\mathrm{US}-812}$ & $46 a^{y}$ & $82 \mathrm{a}$ & $73 \mathrm{a}$ & $159 \mathrm{a}$ & $109 a$ & $140 \mathrm{a}$ & $113 \mathrm{a}$ \\
\hline Carrizo & $19 \mathrm{~b}$ & $65 \mathrm{ab}$ & $35 \mathrm{abc}$ & $128 \mathrm{a}$ & $92 \mathrm{ab}$ & $141 \mathrm{a}$ & $92 \mathrm{ab}$ \\
\hline Swingle & $22 \mathrm{~b}$ & $60 \mathrm{abc}$ & $35 \mathrm{abc}$ & $119 \mathrm{ab}$ & $69 \mathrm{abc}$ & $132 \mathrm{ab}$ & $83 \mathrm{ab}$ \\
\hline Cleopatra & $23 \mathrm{~b}$ & $60 a b c$ & $52 \mathrm{abc}$ & $66 \mathrm{bc}$ & $69 \mathrm{abc}$ & $105 \mathrm{ab}$ & $70 \mathrm{ab}$ \\
\hline Sun Chu Sha & $18 \mathrm{~b}$ & $30 \mathrm{c}$ & $22 \mathrm{bc}$ & $69 \mathrm{bc}$ & $48 \mathrm{bc}$ & $81 \mathrm{~b}$ & $50 \mathrm{bc}$ \\
\hline US-953 & $12 \mathrm{~b}$ & $26 \mathrm{c}$ & $9 \mathrm{c}$ & $32 \mathrm{c}$ & $26 \mathrm{c}$ & $25 \mathrm{c}$ & $24 \mathrm{c}$ \\
\hline
\end{tabular}

${ }^{z}$ Yearly average based on years 5 to 9 .

${ }^{\text {y } M e a n ~ s e p a r a t i o n s ~ f o r ~ s i g n i f i c a n t ~ A N O V A ~ w i t h i n ~ r o w s ~ w e r e ~ b y ~ D u n c a n ' s ~ m u l t i p l e ~ r a n g e ~ t e s t ~ a t ~} P<0.05$.

Table 6. Ambersweet scion in Lake County, years 1996-2001.

\begin{tabular}{lccccccc}
\hline & \multicolumn{9}{c}{ Fruit yield (kg/tree) } & \multicolumn{1}{c}{ Yearly } \\
\cline { 2 - 7 } Rootstock & Year 4 & Year 5 & Year 6 & Year 7 & Year 8 & Year 9 & avg $^{z}$ \\
\hline Carrizo & 25 & $78 \mathrm{a}^{\mathrm{y}}$ & $86 \mathrm{a}$ & $131 \mathrm{a}$ & $81 \mathrm{a}$ & $120 \mathrm{a}$ & $99 \mathrm{a}$ \\
US-812 & 35 & $73 \mathrm{a}$ & $70 \mathrm{a}$ & $85 \mathrm{~b}$ & $80 \mathrm{a}$ & $112 \mathrm{a}$ & $84 \mathrm{ab}$ \\
Cleopatra & 33 & $68 \mathrm{ab}$ & $65 \mathrm{ab}$ & $72 \mathrm{bc}$ & $61 \mathrm{ab}$ & $132 \mathrm{a}$ & $80 \mathrm{ab}$ \\
Swingle & 30 & $43 \mathrm{bc}$ & $42 \mathrm{bc}$ & $106 \mathrm{ab}$ & $56 \mathrm{bc}$ & $124 \mathrm{a}$ & $74 \mathrm{ab}$ \\
Sun Chu Sha & 16 & $41 \mathrm{bc}$ & $34 \mathrm{c}$ & $61 \mathrm{bc}$ & $23 \mathrm{~d}$ & $92 \mathrm{ab}$ & $50 \mathrm{bc}$ \\
US-937 & 19 & $24 \mathrm{c}$ & $17 \mathrm{c}$ & $32 \mathrm{c}$ & $38 \mathrm{~cd}$ & $60 \mathrm{~b}$ & $34 \mathrm{c}$ \\
\hline
\end{tabular}

${ }^{2}$ Yearly average based on years 5 to 8 .

${ }^{y}$ Mean separations for significant ANOVA within rows were by Duncan's multiple range test at $P<0.05$.

Table 7. Yield of Hamlin sweet oranges on US-812 and three other rootstocks in a Collier County trial (kg fruit/tree/season), years 2000-04.

\begin{tabular}{lccccc}
\hline Hamlin clone & Season & US-812 & Citrus obovoideae & US-1001 & X-639 \\
\hline $1-4-1$ & 5 & 97 & 67 & 77 & 34 \\
$1-4-1$ & 6 & $123 \mathrm{a}$ & $88 \mathrm{ab}$ & $130 \mathrm{a}$ & $51 \mathrm{~b}$ \\
$1-4-1$ & 7 & 123 & 59 & 106 & 68 \\
$1-4-1$ & 8 & 172 & 180 & 124 & 96 \\
$8-4-1$ & 5 & 82 & 81 & 60 & 66 \\
$8-4-1$ & 6 & 129 & 113 & 104 & 79 \\
$8-4-1$ & 7 & 144 & 103 & 85 & 88 \\
$8-4-1$ & 8 & 209 & 230 & 105 & 169 \\
Both & $5-8$ & $139 \mathrm{a}$ & $117 \mathrm{ab}$ & $102 \mathrm{ab}$ & $86 \mathrm{~b}$ \\
\hline
\end{tabular}

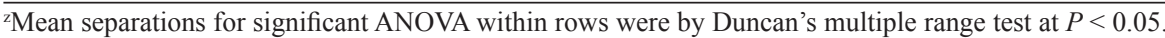

Rows without letters were not significant.

Table 8. Yield of Valencia orange on US-812 and three other rootstocks in a Collier County trial (kg fruit per tree per season), years 2000-04.

\begin{tabular}{lccccc}
\hline Valencia clone & Seasons & US-812 & US-1001 & X-639 & Citrus obovoideae \\
\hline $10-27-7$ & $5-8$ & 88 & 83 & 69 & 56 \\
$1-14-19$ & $5-8$ & 77 & 64 & 94 & 63 \\
RR & $5-8$ & 75 & 77 & 50 & 50 \\
$55-28$ & $5-8$ & 71 & 66 & 48 & 63 \\
$51-3-3$ & $5-8$ & 75 & 60 & 43 & 62 \\
All 5 & $5-8$ & $77 \mathrm{a}^{\mathrm{z}}$ & $70 \mathrm{ab}$ & $61 \mathrm{ab}$ & $59 \mathrm{~b}$ \\
\hline
\end{tabular}

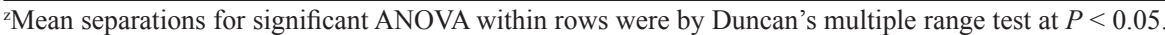

Rows without letters were not significant.

Table 9. Truck cross sectional area and yield of grapefruit in two trials, 2003.

\begin{tabular}{lccccc}
\hline & \multicolumn{2}{c}{$\begin{array}{c}\text { St. Lucie County Trial } \\
\text { @ 4 4 years old }\end{array}$} & & \multicolumn{2}{c}{$\begin{array}{c}\text { Indian River County Trial } \\
\text { @ 3 3 years old }\end{array}$} \\
\cline { 2 - 3 } \cline { 5 - 6 } Rootstock & TCSA $\left(\mathrm{mm}^{2}\right)$ & Fruit yield $(\mathrm{kg} /$ tree $)$ & & TCSA $\left(\mathrm{mm}^{2}\right)$ & Fruit yield $(\mathrm{kg} /$ tree $)$ \\
\hline Rough lemon & $10072 \mathrm{a}$ & $178 \mathrm{a}$ & & --- & --- \\
US-812 & $8930 \mathrm{ab}$ & $166 \mathrm{ab}$ & & $1523 \mathrm{~b}$ & $23 \mathrm{~b}$ \\
Carrizo & $8892 \mathrm{ab}$ & $146 \mathrm{abc}$ & & $987 \mathrm{c}$ & $8 \mathrm{c}$ \\
Sour \#2 & $8220 \mathrm{bc}$ & $135 \mathrm{bcd}$ & & --- & --- \\
Swingle & $7118 \mathrm{c}$ & $126 \mathrm{~cd}$ & & $880 \mathrm{c}$ & $5 \mathrm{c}$ \\
US-802 & $8999 \mathrm{ab}$ & $104 \mathrm{de}$ & & $2284 \mathrm{a}$ & $38 \mathrm{a}$ \\
Sun Chu Sha & $9561 \mathrm{ab}$ & $98 \mathrm{de}$ & & --- & --- \\
Cleopatra & --- & --- & & $1897 \mathrm{ab}$ & $26 \mathrm{~b}$ \\
Flying Dragon & $4759 \mathrm{~d}$ & $78 \mathrm{e}$ & & -- & --- \\
\hline
\end{tabular}

${ }^{2}$ Mean separations for significant ANOVA within rows were by Duncan's multiple range test at $P<0.05$.

al., 2003). Under these challenging conditions that severely damage many common rootstocks (Graham et al., 2003), performance of young trees on US-812 is relatively poor, while a few other new hybrid rootstocks appear much more promising. US-812 does not appear to be a good rootstock for locations infested by Diaprepes weevil and P. palmivora on heavy soil. Research is continuing to identify any other limitations in soil adaptation, disease tolerance, or scion compatibility of US-812 rootstock. 
Table 10. Height (m) of trees on US-812 and other rootstocks in different trials at 6, 7, or 10 years of age, as indicated.

\begin{tabular}{|c|c|c|c|c|c|}
\hline Rootstock & $\begin{array}{l}\text { Valencia in } \\
\text { Polk Co. } \\
\text { (10 years) }\end{array}$ & $\begin{array}{l}\text { Sunburst in } \\
\text { Lake Co. } \\
\text { (7 years) }\end{array}$ & $\begin{array}{l}\text { Ambersweet in } \\
\text { Lake Co. } \\
\text { (7 years) }\end{array}$ & $\begin{array}{l}\text { Fallglo in } \\
\text { Lake Co. } \\
\text { (6 years) }\end{array}$ & $\begin{array}{c}\text { Avg } \% \text { of } \\
\text { Carrizo tree ht }\end{array}$ \\
\hline Vangasay lemon & $4.08 \mathrm{a}$ & --- & --- & --- & $109 \mathrm{a}$ \\
\hline Carrizo & $3.75 \mathrm{ab}$ & $3.10 \mathrm{a}$ & $3.14 \mathrm{a}$ & $2.96 \mathrm{a}$ & $100 \mathrm{ab}$ \\
\hline Gou Tou & $3.61 \mathrm{bc}$ & --- & --- & --- & $96 \mathrm{ab}$ \\
\hline Cleopatra & --- & $2.71 \mathrm{~b}$ & $2.79 \mathrm{ab}$ & $2.74 \mathrm{a}$ & $90 \mathrm{~b}$ \\
\hline US-812 & $3.26 \mathrm{c}$ & $2.76 \mathrm{~b}$ & $2.58 \mathrm{bc}$ & $2.97 \mathrm{a}$ & $90 \mathrm{~b}$ \\
\hline Sun Chu Sha & $3.99 \mathrm{a}$ & $2.64 \mathrm{~b}$ & $2.48 \mathrm{bc}$ & $2.37 \mathrm{~b}$ & $88 \mathrm{~b}$ \\
\hline Swingle & $3.46 \mathrm{bc}$ & $2.63 \mathrm{~b}$ & $2.35 \mathrm{c}$ & $2.89 \mathrm{a}$ & $87 \mathrm{~b}$ \\
\hline US-937 & $2.54 \mathrm{~d}$ & $1.96 \mathrm{c}$ & $1.77 \mathrm{~d}$ & $2.14 \mathrm{~b}$ & $65 \mathrm{c}$ \\
\hline Sour orange \#2 & $1.51 \mathrm{e}$ & --- & --- & --- & $40 \mathrm{~d}$ \\
\hline
\end{tabular}

${ }^{2}$ Mean separations for significant ANOVA within rows were by Duncan's multiple range test at $P<0.05$.

Table 11. Fruit quality of Valencia sweet orange on US-812 and other rootstocks in Polk County. Samples collected on 20 May 2003.

\begin{tabular}{|c|c|c|c|c|c|}
\hline Rootstock & $\begin{array}{c}\text { Fruit } \\
\text { wt } \\
(\mathrm{g})\end{array}$ & $\begin{array}{c}\text { Degree } \\
\text { Brix } \\
(\%)\end{array}$ & $\begin{array}{c}\text { Total } \\
\text { acid }^{z} \\
(\%)\end{array}$ & $\begin{array}{l}\text { Juice/ } \\
\text { box }^{y} \\
(\mathrm{~kg})\end{array}$ & $\begin{array}{c}\text { Soluble } \\
\text { solids/ } \\
\text { box }^{y}(\mathrm{~kg})\end{array}$ \\
\hline$\overline{\text { US-954 }}$ & $222 b^{x}$ & $11.2 \mathrm{a}$ & $0.57 \mathrm{a}$ & $23.8 \mathrm{a}$ & $2.67 \mathrm{a}$ \\
\hline Sour orange \#2 & $217 \mathrm{c}$ & $9.8 \mathrm{~b}$ & $0.43 \mathrm{~d}$ & $24.3 \mathrm{a}$ & $2.39 \mathrm{ab}$ \\
\hline US-812 & $285 \mathrm{a}$ & $9.7 \mathrm{~b}$ & $0.56 \mathrm{ab}$ & $23.2 \mathrm{a}$ & $2.25 \mathrm{bc}$ \\
\hline Swingle & $273 \mathrm{abc}$ & $9.5 \mathrm{~b}$ & $0.56 \mathrm{ab}$ & $22.9 \mathrm{a}$ & $2.18 \mathrm{bcd}$ \\
\hline US-942 & $319 \mathrm{a}$ & $9.6 \mathrm{~b}$ & $0.54 \mathrm{abc}$ & $22.0 \mathrm{ab}$ & $2.14 \mathrm{bcd}$ \\
\hline Carrizo & $286 \mathrm{a}$ & $8.9 \mathrm{~b}$ & $0.51 \mathrm{c}$ & $22.2 \mathrm{ab}$ & $1.98 \mathrm{bcd}$ \\
\hline Sun Chu Sha & $284 \mathrm{a}$ & $8.9 \mathrm{~b}$ & $0.52 \mathrm{bc}$ & $22.0 \mathrm{ab}$ & $1.95 \mathrm{~cd}$ \\
\hline Gou Tou & $278 \mathrm{ab}$ & $8.6 \mathrm{~b}$ & $0.50 \mathrm{c}$ & $21.9 \mathrm{ab}$ & $1.89 \mathrm{~cd}$ \\
\hline Vangasay lemon & $269 \mathrm{abc}$ & $8.9 \mathrm{~b}$ & $0.53 \mathrm{abc}$ & $20.2 \mathrm{~b}$ & $1.81 \mathrm{~d}$ \\
\hline
\end{tabular}

${ }^{\mathrm{z}}$ Acid reported as citric acid.

${ }^{\mathrm{y}}$ Box equals $40.9 \mathrm{~kg}$ of fruit.

${ }^{x}$ Mean separations for significant ANOVA within rows were by Duncan's multiple range test at $P<0.05$.

Table 12. Fruit quality of Hamlin on US-812 and other rootstocks in Collier County. Quality evaluated in January each of three seasons for tree age 5 to 7 years.

\begin{tabular}{lccccc}
\hline & $\begin{array}{c}\text { Fruit } \\
\text { wt } \\
(\mathrm{g})\end{array}$ & $\begin{array}{c}\text { Degree } \\
\text { Brix } \\
(\%)\end{array}$ & $\begin{array}{c}\text { Total } \\
\text { acid }^{z} \\
(\%)\end{array}$ & $\begin{array}{c}\text { Juice/ } \\
\text { box }^{\mathrm{y}} \\
(\mathrm{kg})\end{array}$ & $\begin{array}{c}\text { Soluble } \\
\text { solids/ } \\
\text { box }^{\mathrm{y}}(\mathrm{kg})\end{array}$ \\
\hline US-812 & 161 & 10.7 & $0.57 \mathrm{a}$ & 21.53 & $2.30 \mathrm{a}$ \\
C. obovoideae & 173 & 10.2 & $0.55 \mathrm{ab}$ & 21.47 & $2.19 \mathrm{ab}$ \\
US-1001 & 177 & 10.4 & $0.56 \mathrm{a}$ & 20.48 & $2.13 \mathrm{~b}$ \\
X-639 & 174 & 10.1 & $0.53 \mathrm{~b}$ & 20.56 & $2.08 \mathrm{~b}$ \\
\hline
\end{tabular}

${ }^{\mathrm{z}}$ Mean separations for significant ANOVA within rows were by Duncan's multiple range test at $P<0.05$.

Table 13. Fruit quality of Sunburst tangerine on US-812 and other rootstocks in a Lake County Trial. Samples collected on 18 Nov. 2003. Tree age 7 years.

\begin{tabular}{llcccc}
\hline & $\begin{array}{l}\text { Fruit } \\
\text { diam } \\
(\mathrm{mm})\end{array}$ & $\begin{array}{c}\text { Juice } \\
(\%)\end{array}$ & $\begin{array}{c}\text { Degree } \\
\text { Brix } \\
(\%)\end{array}$ & $\begin{array}{c}\text { Total } \\
\text { acid }^{\mathrm{z}} \\
(\%)\end{array}$ & $\begin{array}{l}\text { Juice } \\
\text { color } \\
(\mathrm{CN}))^{\mathrm{y}}\end{array}$ \\
\hline US-896 & $68.2 \mathrm{c}^{\mathrm{x}}$ & $52.2 \mathrm{ab}$ & $10.18 \mathrm{a}$ & $0.95 \mathrm{a}$ & $43.3 \mathrm{a}$ \\
US-812 & $68.9 \mathrm{bc}$ & $50.5 \mathrm{ab}$ & $10.12 \mathrm{~b}$ & $0.94 \mathrm{ab}$ & $42.5 \mathrm{ab}$ \\
Swingle & $70.3 \mathrm{abc}$ & $53.2 \mathrm{a}$ & $10.10 \mathrm{bc}$ & $0.85 \mathrm{c}$ & $42.5 \mathrm{ab}$ \\
Carrizo & $70.7 \mathrm{ab}$ & $45.5 \mathrm{~b}$ & $10.06 \mathrm{~cd}$ & $0.88 \mathrm{bc}$ & $42.2 \mathrm{bc}$ \\
Flying Dragon & $71.4 \mathrm{a}$ & $46.0 \mathrm{~b}$ & $10.04 \mathrm{~d}$ & $0.76 \mathrm{~d}$ & $41.5 \mathrm{c}$ \\
\hline
\end{tabular}

${ }^{2}$ Acid reported as citric acid citric.

${ }^{y} \mathrm{CN}=$ color number as measured in Greytag MacBeth Color Eye Spectrophotometer.

${ }^{x}$ Mean separations for significant ANOVA within columns were by Duncan's multiple range test at $P<0.05$.

\section{Availability}

Disease-indexed budwood to establish seed trees is being distributed by Florida Department ofAgriculture (Division of Plant Industry, 3027 Lake Alfred Road, Winter Haven, FL 33881) to registered Florida citrus nurseries. Requests for budwood from other states or countries should be sent to the USDA-ARS National Clonal Germplasm Repository for Citrus (1060 Martin Luther King Blvd., Riverside, CA 92507). Seed for commercial propagation may be available from commercial nurseries, Florida Department of Agriculture, or Florida Citrus Nurserymen's Association.

\section{Literature Cited}

Bowman, K.D. 1998. Performance of 'Fallglo'Citrus Hybrid on Ten Rootstocks in Lake County. Proc. Fla. State Hort. Soc. 111:177-180.

Bowman, K.D., J.P. Albano, and J.H. Graham. 2002. Greenhouse testing of rootstocks for resistance to Phytophthora species in flatwoods soil. Proc. Fla. State Hort. Soc. 115:10-13.

Bowman, K.D. and S.M. Garnsey. 2001.Acomparison of five sour orange rootstocks and their response to citrus tristeza virus. Proc. Fla. State Hort. Soc. 114:73-77.

Bowman, K.D.,J.H. Graham, and R.C.Adair, Jr. 2003. Young tree growth in a flatwoods rootstock trial with Diaprepes weevil and Phytophthora diseases. Proc. Fla. State Hort. Soc. 116:249-251.

Bowman, K.D. and F.M. Roman. 1999. New rootstocks for orange and mandarin. Proc. Caribbean Food Crops Soc. 35:119-130.

Bowman, K.D., J.P. Shapiro, and S.L. Lapointe. 2001. Sources of resistance to Diaprepes weevil in subfamily Aurantiodeae, Rutaceae. HortScience 36:332-336.

Bowman, K.D. and H.K. Wutscher. 2001. Notice to fruit growers and nurserymen relative to the naming and release of the US-812 citrus rootstock. USDA-ARS, Wash., D.C.

Graham, J.H., D.B. Bright, and C.W. McCoy. 2003. Phytophthora-Diaprepes weevil complex: Phytophthora spp. relationship with citrus rootstocks. Plant Dis. 87:85-90.

McCollum, T.G., K.D. Bowman, and W.S. Castle. 2002. Effects of rootstock on fruit quality and postharvest behavior of 'Marsh' grapefruit. Proc. Fla. State Hort. Soc. 115:44-46.

Ritenour, M.A., H. Dou, K.D. Bowman, B.J. Boman, E. Stover, and W.S. Castle. 2004. Effect of Rootstock on Stem-End Rind Breakdown and Decay of Fresh Citrus. HortTechnology 14(3):315-319.

Wutscher, H.K, M. Cohen, and R.H. Young. 1977. Zinc and water soluble phenolic levels in the wood for diagnosis of citrus blight. Plant Dis. Rptr. 61:572-574.

Wutscher, H.K. and K.D. Bowman. 1999. Performance of 'Valencia' orange on 21 rootstocks. HortScience 34:622-624. 